\title{
PHYSICO - MICROBIOLOGICAL EXAMINATIONS OF DOMESTIC WATER USED BY THE COMMUNITY OF COLLEGE OF AGRICULTURE AND ITS ENVIRONS, MAIDUGURI, NORTH - EASTERN NIGERIA
}

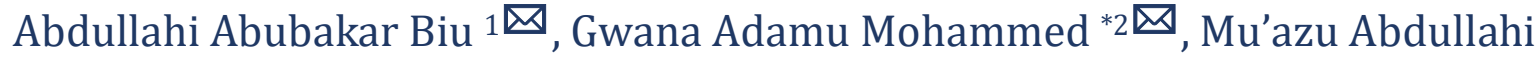 \\ Kofar Na'isa ${ }^{3} \boldsymbol{\Xi}$, Abubakar Musa ${ }^{4}$, Abubakar Aliyu ${ }^{5} \boldsymbol{\Xi}$, Mohammed Lawan Marte 6 \\ ${ }^{1}$ Department of Veterinary Microbiology and Virology, Faculty of Veterinary Medicine, University \\ of Maiduguri, Maiduguri, Nigeria \\ ${ }^{2}$ Laboratory Unit, Department of Animal Health and Production Technology, Mohamet Lawan \\ College of Agriculture, Maiduguri, Nigeria \\ 3 Department of Planning, Research and Development, Nigerian Institute of Science Laboratory \\ Technology, Ibadan, Nigeria \\ ${ }^{4}$ Department of Basic Science and Technology, Mohamet Lawan College of Agriculture, Maiduguri, \\ Nigeria \\ ${ }^{5}$ Department of Forestry Technology, Mohamet Lawan College of Agriculture, Maiduguri, Nigeria \\ ${ }^{6}$ Department of Geography, Kashim Ibrahim College of Education, Maiduguri, Nigeria
}

DOI: https://doi.org/10.29121/granthaalayah.v8.i7.2020.226

Article Type: Research Article

Article Citation: Abdullahi Abubakar Biu, Gwana Adamu Mohammed, Mu'azu Abdullahi Kofar Na'isa, Abubakar Musa, Abubakar Aliyu, and Mohammed Lawan Marte. (2020). PHYSICO - MICROBIOLOGICAL EXAMINATIONS OF DOMESTIC WATER USED BY THE COMMUNITY OF COLLEGE OF AGRICULTURE AND ITS ENVIRONS, MAIDUGURI, NORTH - EASTERN NIGERIA. International Journal of Research -GRANTHAALAYAH, 8(7), 362-373. https://doi.org/10.29121/granthaalayah.v8.i7.2020.226

Received Date: 16 May 2020

Accepted Date: 31 July 2020

Keywords:

Domestic Activities

Health-Risks

Potable Water

Standard Values

Water Sanitation

\section{ABSTRACT}

This research study focuses on the importance to evaluate the types and their quality, beneficial uses of waters in order to ascertain its assess, contaminations and the impacts of pollution. Study was conducted on Physico microbiological examinations of domestic water used by the Community of College of Agriculture and its environs, Maiduguri. Methods used were that described by Cheesbrough [1], Gwana et al., [2], and AOAC [3]. 200 mls of water sample from 8 water stations (A to H) were each sampled. Results obtained revealed the colour, odour and taste of the water sampled were normal, except station E, which was brownish in colour and perceived fishy smelt and tasted

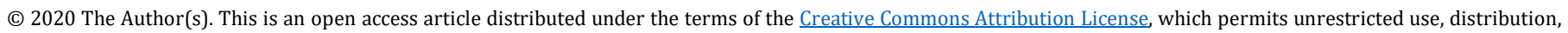
and reproduction in any medium, provided the original author and source are credited. 
salty, mean $\mathrm{pH}$ values ranged from of 6.6 to 8.2 , mean temperature (OC) from ranged from 22.1 to 32.1 OC, mean turbidity (TU) from ranged from 1 to 4 TU. Microscopical examination of the water sampled in each of the stations using parasitological techniques; there was no protozoan cysts, protozoan trophozoites, helminths ovae (eggs) and helminths adult parasites found, except in water station E where larva of Schistosoma species (Bifurcated Cercaria) was seen. For the bacteriological examination, the indicators used were Coliform, Escherichia coli, and Aerobic mesophilic bacteria, values were given in mean coliform unit per mills (CFU / mls) of the water sampled. Stations; A and B, had yielded growth of coliform each with $0, C, F, G$ and $\mathrm{H}$ each had 1, D (5), and E (94). Escherichia coli; station A had 1, and B, C, F, and G had 0 each, 22, 56, and 18 for D, E, and H. Aerobic mesophilic bacteria; station A had 283, B (23), C (103), D (261), E (313), F (51), G (11) and H had 286 CFU / mls. The water stations were found free from health hazards, therefore, fit for consumption and domestic activities, except water from station E. There is a needs to be enlightened the community on safe - drinking water measures in the study area.

\section{INTRODUCTION}

When dealing with global warming; including the climatic change, its environmental impacts and food security, the uses and benefits of water should not be left behind. It is important to evaluate the types and beneficial uses of waters in order to ascertain its accessibly, availability, suitability (taste, odour, and appearance,) affordability, assess the contaminations and the impacts of pollution. For many decades, the certainty of water and its supplies has determined where settlement or inhabitance (hamlets, villages, towns, and cities) are sited. Water is essential to all living things and the quantity and quality of any potable water should meet local standards for the purpose of health risk free.

Historically, the available of water supplies has determined where villages, towns, and cities are sited. Nomadic peoples and animals may travel hundreds of miles over the course of a year following the seasonal variation in rainfall [1], [2]. Water is a universal solvent used for various purposes. It contains dissolved elements and metals in various quantities [4]. The domestic water use includes drinking, food preparation, washing of clothes, cooling machine, keeping ourselves and environment clean, for garden and service industries. Although most of the water used for industrial purposes is returned to the water cycle, and it is often contaminated with microbiological agents, some chemical and heavy metals [5], [6].

Water is the basic of life on which all life depends on for survival. It is a very valuable but finite natural renewable resource, hence, the need for proper planning, management, and development of this valuable resource in order to prevent pollution as well as to harmonize its availability when the demand for different uses become necessary [7], [8], [9]. If the importance of a nutrient is judged by how long we can do without it, water ranks as the most important. A person can survive only eight to ten days without water, whereas it takes weeks or even months to die from a lack of food. Water circulates through our body and lymphatic system, transporting oxygen and nutrients to cells and removing wastes through urine and sweat. Water also maintains the natural balance between dissolved salts and water inside and outside of cells. Our joints and soft tissues depend on the cushioning that water provides for them. While water has no caloric value and therefore is not an energy source, without it in our diets we could not digest or absorb the foods we eat or eliminate the body's digestive waste [10], [11], [12], [13]. According to WHO [14], many water sources in developing countries are unhealthy; this is because they contain harmful physical, chemical and biological agents.

Water pollution is the contamination of streams, lakes, underground water, bays, or oceans by substances harmful to living things. Water is necessary to life on earth. All organisms contain it, some live in it, and some drink it. Plants and animals require water that is moderately pure, and they cannot survive if their water is loaded with toxic chemicals and harmful microorganisms. If severe, water pollution can kill large numbers of fish, birds, and other animals, in some cases killing all members of species in an affected area. Pollution makes streams, lakes and coastal water unpleasant to look at, to smell, and to swim in it. Fish and shellfish harvested from polluted waters may be unsafe to eat. People who ingest polluted water can become ill, and with prolonged exposure, may develop cancers or bear children with birth defects [1], [12].

A 1994 study, conducted by the Centre for Disease Control and Prevention (CDC - P), estimated that about 900,000 people get sick annually in the United States because of organisms in their drinking water, and around 900 
Physico - Microbiological Examinations of Domestic Water Used by The Community of College of Agriculture and Its Environs, Maiduguri, North - Eastern Nigeria

people die. Many disease-causing organisms that are present in small numbers in most natural waters are considered pollutants when found in drinking water. Such parasites as Giardia lamblia and Cryptosporidium parvum occasionally turn up in urban water supplies. Parasites can cause illness, especially in people who are very old or very young, and in immunocomprised persons. In 1993, an outbreak of Cryptosporidium in the water supply of Milwaukee, Wisconsin, sickened more than 400,000 people and killed more than 100 [15].

A lack of good quality drinking water, and water sanitation, brings deadly illness such as typhoid [1], [14], [16], estimated that 2.6 billion people have no access to improved sanitation facilities. Water is a life supporting resource and the importance of water as a resource is not only tied to its quantity and availability, but also to its quality in terms of table water [6], [17]. Water system may be static (lentic) such as lakes, reservoirs, or flowing (lotic) such as rivers, rainwater, ditches, and streams [18], [19]. Fresh water quality is not constant; it varies with the time of the day, season, weather conditions, water source, soil type, temperature, stocking density, and feeding rate [19], [20]. Virtually, water quality management must be maintaining, a change in one of these factors may result in change to one or more of the other factors that have been reported to affect the quality of a water body [17], [21].

A safe drinking water should conform to the following water quality characteristic; it should be free from pathogenic organisms, low in concentration of compounds that are toxic to man, livestock, and plants, and finally free from compounds that cause offensive taste and odour [22]. In a publication, 'Safe water, better healthy' by Word Health Organization in 2008, it was estimated that almost one tenth (1 / 10) of the global disease burden could be prevented by improving water supply, sanitation, hygiene and management of water resources. It is estimated 1.5 million children die each year from diarrhoea due to unsafe water, inadequate sanitation or insufficient hygiene [1]. Growth and nutrition in young children are also adversely affected by contaminated water supplies, poor hygiene and inadequate sewerage. The United Nations had declared 2005 to 2015, the 'Water for Life Decade' with focus on water - related issues and a goal of having by 2015 reducing the number of people with no access to sustainable safe drinking water and basic acceptable sanitation. Among the issues identified as priority for decades (i.e. safe water, better - health - water for life decade) are water scarcities, sanitation access, disaster prevention, trans - boundary water issues, gender issues, capacity - building, financing, valuation, integrated water resources management, environment and biodiversity, food and agriculture, pollution and energy [1]. All these factors and many more, make water a substance of great importance. From a strictly chemical point of view, the remarkable thing about water is the amount of hydrogen bonding it has, both in the solid (ice), gaseous (steam) and in the liquid form. If it were not for the fact that hydrogen bonds are of intermediate strength (stronger than Van der Waals bonds but weaker than ordinary ionic or covalent bonds) then life as we know it could not exist and the world would be without rivers, lakes, or seas [16], [20], [23].

To maintain good health, however, not only must a water supply be safe to drink, it must also be; available in sufficient quantity for cooking, hand washing, personal bathing, cleaning and laundering clothes. Easily and safely accessible by all the community without the need to carry heavy containers of water over long distances or having containers of water harbouring insects' vectors of disease. Available all the time or when it is needed and finally available at affordable cost and it should also meet local standards for taste, odour, and appearance [1], [14]. Many water sources in the developing countries are unhealthy, contain harmful physical, compound agents. This is not different with said the community of College of Agriculture, Maiduguri, and Nigeria at large. This necessitate research study to be conducted within the said study area, source of water stations is to be involved and the study will have revealed useful information on some of the quality levels of the water used. The objectives of the Study to determine the Physico - microbiological examinations of domestic water used by the community of College of Agriculture, Maiduguri, North - Eastern Nigeria.

\section{METHODOLOGY}

\subsection{STUDY AREA AND LOCATION}

The study was conducted within the community of Mohamet Lawan College of Agriculture and its environs, Maiduguri. Borno State of Nigeria. The State is located in the North - Eastern region of Nigeria, and is among the six geo - political zones of the Federal Republic of Nigeria. Maiduguri shares local boundaries with Konduga, Jere and Mafa Local Government areas, with majority of the local people are small scale business men, farmers, fishermen 
and herdsmen, Islamic and Western Scholars do exist [24]. The major languages are Kanuri, Shuwa - Arab, Fulfulde, Hausa and English respectively. Maiduguri has an area land-mark of about $300 \mathrm{~km} 2$, which lies between latitude 120 North to 130 North and longitude 13o East to 150 East respectively. It has an estimated population of about 629,486 people, out of which 340, 809 are males and 288, 977 are females [25]. The climatic condition in this area is of a hot dry season ( $27 \mathrm{oC}$ to $42 \mathrm{oC}$ ), and an annual rainfall of 500 to $600 \mathrm{~mm}$ has been recorded [24].

\subsection{MATERIALS USED}

All materials, reagents and culture media used for this analysis were of highly analytical grade.

\subsection{METHODS USED}

The methods used in the course of this research study were the physical and microbiological techniques, as in the methods described by Cheesbrough [1], Gwana et al., [2] and AOAC [3]. The methods were divided into seven experimental stages. These stages were: - Water samples collection from eight stations within the study area, measurements of the $\mathrm{pH}$, temperature, turbidity, determination of the colour and aesthetics of the water samples and the microbiological techniques (bacteriological and parasitological techniques).

\subsubsection{WATER SAMPLING AND SAMPLES COLLECTION}

Procedure: The study area was randomly divided in to eight stations, namely; station A, B, C, D, E, F, G and H. At 6:00 AM hours (in the morning hours), 200 mls of pooled water samples were collected in to sterile plastic bottles from each station. It was properly screwed capped and labeled with the following information; date and time of collection, name of the station, and volume of water sample collected. The water samples were packed in a cold chain container (Avoid deterioration and autolysis if any) and transported to the Laboratory for analysis. Sample of water was taken from the various water stations as recommended and with the accordance of the method described by Cheesbrough [1] and Gwana et al., [2]).

\subsubsection{WATER SAMPLED STATION AREAS}

1) Station A: This is situated between the female and male students' hostels of the College. It is a concrete Reservoir 'Dam' constructed for the purposes of reserving and storing of water from tube well which was connected through polythene pipe. Water sample was tapped according to the method described by Cheesbrough [1] and Gwana et al., [2].

2) Station B: This station is situated behind Forestry Technology Department. It is an overhead tank connected to a tube well 'Bore - Hole' for the purposes of storage of water. Gwana et al., [2]

3) Station C: This station is at the Nursery unit of the Forestry Technology Department of the College. It is also a concrete reservoir which is connected to a Bore - Hole just nearby. Water sample was collected according to the method described by Cheesbrough [1] and Gwana et al., [2].

4) Station D: This water station is located at the College Livestock Ban, which is a tube well connected to surface tank and water fed large troughs or basins and a reservoir purposely constructed and made for feeding the livestock. Water sample was collected according to the method described by Cheesbrough [1] and Gwana et al., [2].

5) Station E: This water station is a river Kumodu Gana, which passes through the college farm down to Jere basin where it empties it content to the fields. To this river, domestic wastes, influents from the abattoir and tannery flow down in to the river. Also, wastes from farmers and their washed away of their tools, and the rain falls wash off both fertilizers which run down in to the river as contaminants. Water samples were collected according to the method described by Cheesbrough [1] and Gwana et al., [2].

6) Station F: This is a tube well connected to a concrete reservoir through a polythene pipe which is located at the Borno State Agriculture Mechanisation Agency (BOSAMA), which is adjacent to the College. Water sample was tapped according to the method described by Cheesbrough [1] and Gwana et al., [2]. 
Physico - Microbiological Examinations of Domestic Water Used by The Community of College of Agriculture and Its Environs, Maiduguri, North - Eastern Nigeria

7) Station G: This water station is a tube well connected to a mechanical pump which is located at Farm Centre Quarters. Water sample was tapped according to the method described by Cheesbrough [1] and Gwana et al., [2].

8) Station H: The water station $\mathrm{H}$, is a reservoir connected to a Bore - hole at Alhaji Dawuds' compound and premises, which was located at Goni Kachallari village opposite Mohamet Lawan College of Agriculture, Maiduguri. Water was sampled according to the method described by Cheesbrough [1] and Gwana et al., [2].

\subsubsection{ASSESSMENT OF COLOUR AND ORGANOLEPTIC (AESTHETIC), ODOUR AND TASTE}

Procedure: Experiments was conducted where $100 \mathrm{mls}$ of the collected water samples from each of the eight stations were subjected to an assessment. 24 volunteers (person) were chosen to assess and make observations on the colour, odour and taste of the water samples. They were grouped in to three. Each group had eight members. Each member of a group was issued with an information form (in form of simple structured and closed - ended questionnaire) for the purpose of data collection on the colour, odour and taste of the water sampled. The filled - in forms were retrieved from the volunteers. Data obtained was recorded, analysed and the results collected are in triplicate fold, that is, three times).

\subsubsection{MEASUREMENTS OF PH OF THE WATER SAMPLED}

Procedure: The $\mathrm{pH}$ of the water samples was measured by using digital $\mathrm{pH}$ meter at the point of sample collection. This was done by deepening the electrodes point of the pH meter in to the water sample for thirty (30) seconds; reading was taken and recorded. It was then rinsed with distilled water and deionised water finally.

\subsubsection{MEASUREMENTS TEMPERATURE OF THE WATER SAMPLED}

Procedure: This was performed by deepening the bulb end of the thermometer for one (1) minute and the readings were recorded, and then rinsed with distilled and deionised water after each reading taken and was recorded.

\subsubsection{MEASUREMENTS OF TURBIDITY OF THE WATER SAMPLES BY USING A CALIBRATED 5 - 25 TU TURBIDITY TUBE (PT 513)}

Procedure: The two tubes were joined together by passing the upper tube into the lower one and the black cross at the bottom of the tube was seen and noted. The tube was held over a white surface (a white tile surface), viewed through the tube, then the water sample was dispensed slowly in to the tube until the black cross was no longer visible. The formation of air bubbles was avoided. The turbidity unit, that is, the graduation which corresponded to the meniscus (level) was taken and recorded.

\subsubsection{PARASITOLOGICAL EXAMINATION (MICROSCOPICALLY) OF WATER SAMPLED}

Procedure: The water sample was mixed thoroughly by turning the container up and down, and side by side gently. $10 \mathrm{mls}$ of the mixed sample was dispensed in to a centrifuge tube and screw capped. The centrifuge tube containing the sample was then inserted in to the centrifuge bucket and balanced. The centrifuge machine was then set on and adjusted to 2,000 revolutions per minute for five (5) minutes respectively. The centrifuge machine was put off, allowed to stop by itself after the timed period adjusted without disturbing it, and the tubes were removed from the centrifuge machine and the supernatant decanted. The bottom of the tube was rocked and agitated to detach the deposits or sediments. 
Abdullahi Abubakar Biu, Gwana Adamu Mohammed, Mu’azu Abdullahi Kofar Na'isa, Abubakar Musa, Abubakar Aliyu, and Mohammed Lawan Marte

\subsubsection{MICROSCOPICALLY EXAMINATION}

Procedures: On to the centre of sterile clean grease free slide, two drops of the deposits was placed and covered with a clean grease free cover slip, formation of air bubbles and oozing out of the fluid (deposit) through the sides of cover slip were avoided. This was then mounted on to the stage of microscope, examined with x10 and x40 objective lenses for the presence of cysts, trophozoites, ova, larvae and or adult of parasites and the results were recorded.

\subsubsection{MICROBIOLOGICAL (BACTERIOLOGICAL) EXAMINATION OF FAECAL CONTAMINATION OF WATER SAMPLED}

Microbiological (bacteriological) Examination of faecal contamination of water sampled by using the plate Count, presumptive Coliform count (Multiple tubes technique) and confirmatory Coliform test techniques as described by Cheesbrough [1]. Each test was done in triplicate, as per the method described by Gwana et al. [20].

\subsubsection{PLATE COUNT}

Procedure: A $0.1 \mathrm{ml}$ of the water sampled was inoculated on to a nutrient agar plate. The inoculated plate was then incubated at $37 \mathrm{OC}$ for 24 hours. This was done on triplicate plates. After 24 hours, the number of colonies per plate was counted.

\subsubsection{PRESUMPTIVE COLIFORM COUNT (MULTIPLE TUBES TECHNIQUE)}

Procedure: Fifteen sterile tubes containing inverted Durham tubes were arranged and divided in to 3 sets of five. $10 \mathrm{mls}$ of double strength MacConkey broth medium was dispensed in to each of the tube. The first five sets were inoculated with $10 \mathrm{mls}$ of the inoculum (water sample), then the second five sets of the tubes were inoculated $1 \mathrm{ml}$ of the inoculum, while the third five sets of the tubes were inoculated with $0.1 \mathrm{ml}$ of the inoculum. The tubes were mixed thorough and incubated at 37 OC for 24 hours and up to 48 hours respectively. These tubes were then observed for gas production or colour change of the broth from violet to yellow in the inverted Durham tubes within the said incubated period which indicated a positive presumption test.

\subsubsection{CONFIRMATORY TOTAL COLIFORM TEST TECHNIQUE}

Procedure: A loopful of the colony from the positive presumptive test was inoculated in to brilliant green broth medium which contains Durham tubes. It was incubated at $37 \pm 0.5$ OC for 24 hours. It was then observed for the presence of gas production which confirms the presence of bacteria. The presence of colonies indicated probable identity for typical Coliform. Green stained portion, shows confirmed Coliform and those with a greenish stain confirms the presence of E. coli, while those without any colouration indicated negative.

\subsection{STATISTICAL DATA ANALYSIS}

Data obtained from this research study was subjected to statistical analysis using mean for the measurement of central tendency, and standard deviation for measurement of dispersion and or discrepancy within the variables, as described by Stroud and Booth [26].

\section{RESULTS}

The results of the assessment of colour and organoleptic (aesthetic) appearance of the water sampled from the eight water stations examined. The colour, odour and taste of the water samples was normal, except water sample from station E, which was brownish in colour and perceived, smelt a fishy odour and tasted salty.

Table 1 showed the results of the mean physical parametric values ( $\mathrm{pH}$, temperature, and turbidity) of the water sampled and examined from the eight stations mentioned. The mean $\mathrm{pH}$ of the water samples was within the range 
of 6.6 to 8.2; sample A had 6.6, B (7.1), C (7.2), D (7.6), E (8.0), F (8.2), G (6.7) and H (7.2). The mean temperature (OC) of the water samples ranged from 22.1 to 32.1 OC; sample A had 29.5, B (30.7), C (29.1), D (30.2), E (25.7), F (32.1), G (25. 2) and $H$ (22.1). Then, the mean turbidity (TU) of the water samples ranged from 1 to 4 TU; water sample A had 1 TU, B (1), C (2), D (2), E (4), F (2), G (1) and H had 2 turbidity units respectively.

Table 2 showed the results of the microscopical examination of the water sampled in each of the eight water stations by using parasitological techniques. In water from station A, B, C, D, E, F, G and H there was no protozoan cysts found. Protozoan trophozoites were not found in all of the water stations, same with Helminths ovae. Helminths larvae were not seen in all of the stations, except water station E where larva of Schistosoma species (Bifurcated Cercaria) was seen (present). Helminths adult parasites were not seen (absent) in all of the water stations A, B, C, D, E, F, G and H respectively.

Table 3 showed the results of the bacteriological examination of the water sampled in each of the eight water stations. The indicators used were Coliform, Escherichia coli, and Aerobic mesophilic bacteria, values were given in mean coliform unit per mills (CFU / mls) of the water sampled. Water sampled from stations; A, had yielded growth of coliform $0 \mathrm{CFU} / \mathrm{mls}, \mathrm{B} \quad(0 \mathrm{CFU} / \mathrm{mls}), \mathrm{C}(1 \mathrm{CFU} / \mathrm{mls}), \mathrm{D}(5 \mathrm{CFU} / \mathrm{mls}), \mathrm{E}$ (94 CFU / mls), F (1 CFU / mls), G (1 CFU / mls) and $\mathrm{H}$ had $1 \mathrm{CFU} / \mathrm{mls}$. For yielded growth of Escherichia coli, station A had $1 \mathrm{CFU} / \mathrm{mls}$, and $0 \mathrm{CFU} /$ mls, $0 \mathrm{CFU} / \mathrm{mls}, 22 \mathrm{CFU} / \mathrm{mls}, 56 \mathrm{CFU} / \mathrm{mls}, 0 \mathrm{CFU} / \mathrm{mls}, 0 \mathrm{CFU} / \mathrm{mls}$ and $18 \mathrm{CFU} / \mathrm{mls}$ for B, C, D, E, F, G and H. The examination of the sampled water yielded growth of Aerobic mesophilic bacteria from the eight stations; station A had 283 CFU / mls, B (23 CFU / mls), C (103 CFU / mls), D (261 CFU / mls), E (313 CFU / mls), F (51 CFU / mls), G (11 CFU / mls) and $\mathrm{H}$ had $286 \mathrm{CFU} /$ mls respectively.

Table 1: Physical Parametric Mean \pm SD Values of Water Sampled

\begin{tabular}{|c|c|c|c|}
\hline Water Sampled & \multicolumn{3}{|c|}{ Physico - Parametric Values } \\
\cline { 2 - 4 } Stations (200 mls). & $\mathrm{pH}$ & Temperature $\left({ }^{\circ} \mathrm{C}\right)$ & Turbidity (TU) \\
\hline A & $6.6 \pm 2.4$ & $27.5 \pm 0.3$ & $1 \pm 0.1$ \\
\hline B & $7.1 \pm 0.1$ & $30.7 \pm 0.2$ & $1 \pm 0.1$ \\
\hline C & $7.2 \pm 0$ & $29.1 \pm 0.6$ & $2 \pm 0$ \\
\hline D & $7.6 \pm 0.1$ & $30.2 \pm 0$ & $2 \pm 0.1$ \\
\hline E & $8.0 \pm 0.1$ & $25.7 \pm 0.1$ & $4 \pm 0$ \\
\hline F & $8.2 \pm 0.1$ & $32.1 \pm 0.1$ & $2 \pm 0.1$ \\
\hline G & $6.7 \pm 0$ & $25.2 \pm 0.5$ & $1 \pm 0.1$ \\
\hline H & $7.2 \pm 0.1$ & $22.1 \pm 0$ & $2 \pm 0$. \\
\hline
\end{tabular}

Keys: - mls $=$ Millitres, $\mathrm{pH}=$ Hydrogen ions Concentration, $\mathrm{OC}=$ Degree Celsius, $\mathrm{TU}=$ Turbidity Unit.

Table 2: Parasites Detected in Water Samples Using Parasitological Technique

\begin{tabular}{|l|cccccccc|}
\hline Parasites types Search. & \multicolumn{7}{|c|}{ Water Sampled from each Station (phf) } \\
\cline { 2 - 9 } & A & B & C & D & E & F & G & H \\
\hline Protozoan Cysts & - & - & - & - & - & - & - & - \\
Protozoan Trophozoites & - & - & - & - & - & - & - & - \\
Helminths Ovae & - & - & - & - & - & - & - & - \\
Helminths Larvae & - & - & - & - & ++ & - & - & - \\
Helminths Adult Parasites & - & - & - & - & - & - & - & - \\
\hline
\end{tabular}


Abdullahi Abubakar Biu, Gwana Adamu Mohammed, Mu'azu Abdullahi Kofar Na'isa, Abubakar Musa, Abubakar Aliyu, and Mohammed Lawan Marte

Table 3: Bacteria Isolated from Water Sampled from the Eight Water Stations

\begin{tabular}{|c|c|c|c|c|c|c|c|c|}
\hline \multirow{2}{*}{$\begin{array}{c}\text { Types of Bacteria } \\
\text { Isolated (Indicators) }\end{array}$} & \multicolumn{8}{|c|}{ Stations of Water Samples (CUF / mls) } \\
\hline & A & $\mathrm{B}$ & $\mathrm{C}$ & $\mathrm{D}$ & $\mathrm{E}$ & $\mathrm{F}$ & G & $\mathrm{H}$ \\
\hline Coliform & $0 \pm 0$ & $0 \pm 0$ & $1 \pm 0$ & $5 \pm 0.71$ & $\begin{array}{l}94 \pm \\
0.71\end{array}$ & $1 \pm 0$ & $1 \pm 0$ & $1 \pm 0$ \\
\hline Escherichia coli & $1 \pm 0.71$ & $0 \pm 0$ & $0 \pm 0$ & $\begin{array}{l}22 \pm \\
1.41\end{array}$ & $\begin{array}{l}56 \pm \\
0.71\end{array}$ & $0 \pm 0$ & $0 \pm 0$ & $18 \pm 0$ \\
\hline $\begin{array}{l}\text { Aerobic mesophilic } \\
\text { Bacteria }\end{array}$ & $\begin{array}{ll}283 & \pm \\
0.71 & \end{array}$ & $\begin{array}{ll}23 & \pm \\
0.71 & \end{array}$ & $\begin{array}{ll}103 & \pm \\
1.41 & \end{array}$ & $\begin{array}{ll}261 & \pm \\
1.41 & \end{array}$ & $\begin{array}{ll}313 & \pm \\
2.83 & \end{array}$ & $\begin{array}{ll}51 & \pm \\
1.41 & \end{array}$ & $\begin{array}{ll}11 & \pm \\
0.71 & \end{array}$ & $\begin{array}{ll}286 & \pm \\
1.41\end{array}$ \\
\hline
\end{tabular}

Keys: CFU / mls = Coli Form Unit per Miles. WHO / AOAC Recommended Standard Values (2007 / 2008); 1 $\mathrm{CFU} / \mathrm{ml}$ for Coliform, $0 \mathrm{CFU} / \mathrm{ml}$ for Escherichia coli and $300 \mathrm{CFU} / \mathrm{ml}$ for Aerobic mesophilic Ba

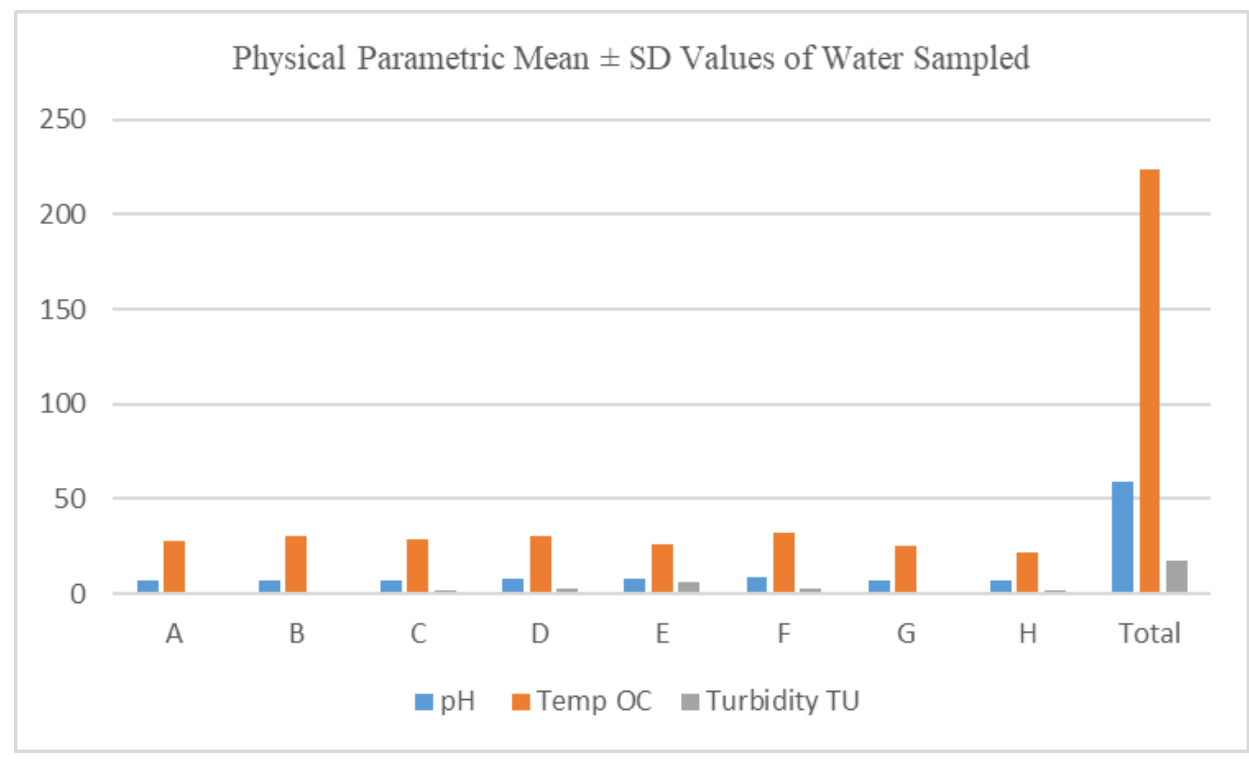

Figure 1: Showed the physical parametric mean values of Water Sampled from the 8 water stations in study area.

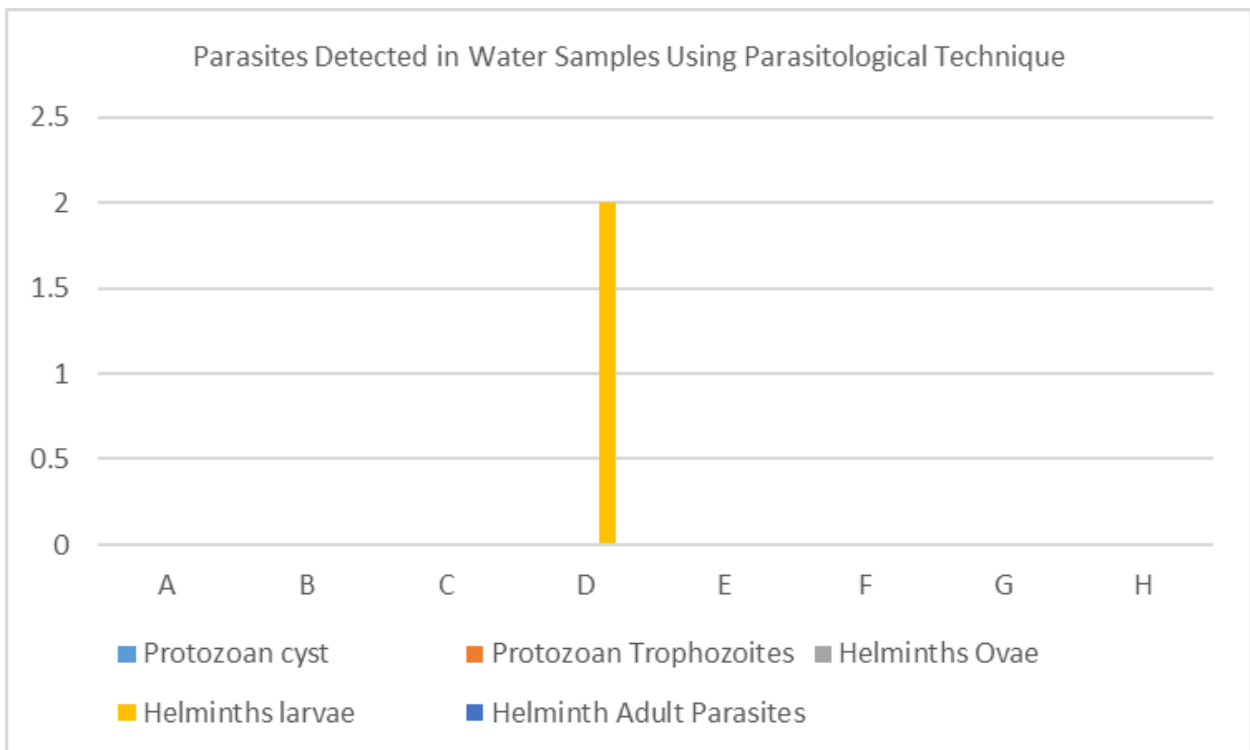

Figure 2: Showed the graph presentation of the parasite detected in the water sampled from the 8 water stations in study area by using parasitological techniques. 
Physico - Microbiological Examinations of Domestic Water Used by The Community of College of Agriculture and Its Environs, Maiduguri, North - Eastern Nigeria

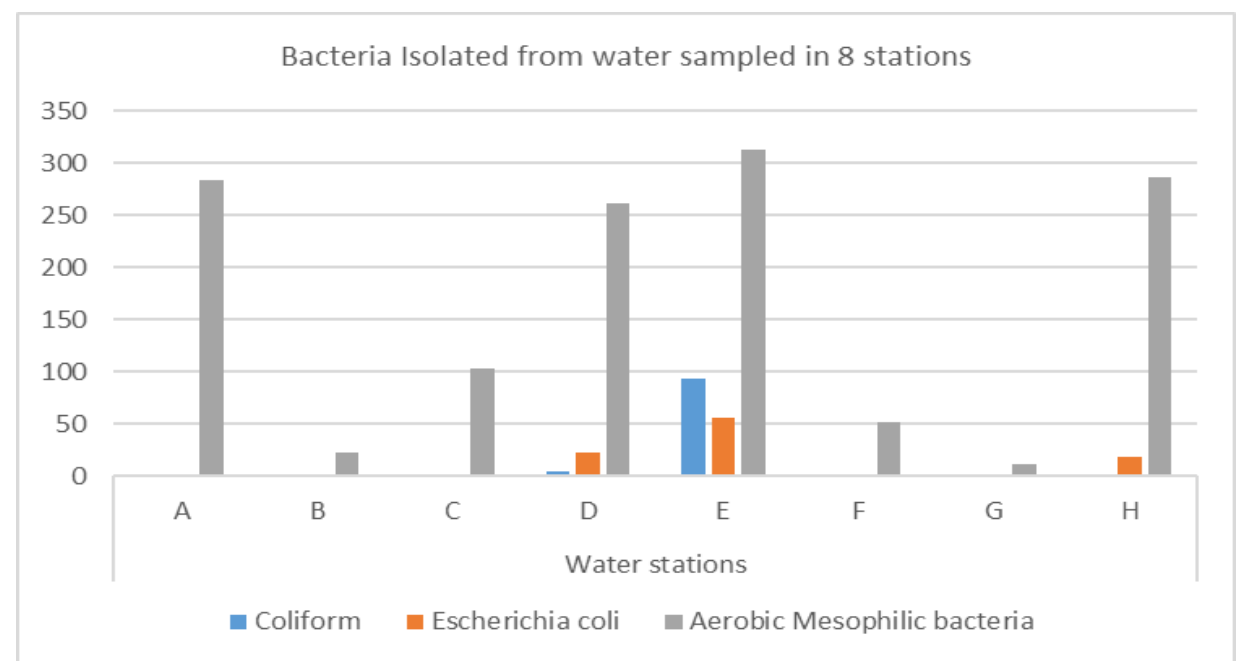

Figure 3: Showed the graph presentation of the bacterial indicators isolated from the water sampled from the 8water station in study area.

\section{DISCUSSION}

Recently, in some years, global warming and the climatic change have caused some problems to environment and food security, especially in terms of water for consumption and domestic purposes. Human activities, especially on rivers, streams, ditches, basins, dams, ponds and water reservoirs, etc., contaminate the waters. Human and animal's activities, affects environmental waters bodies by dispersion of either one or both of the followings; defecation or domestic or industrial wastes materials there by contaminating their only water sources probably, and causes risk of health hazards. In the community of College of Agriculture and its environs, Maiduguri, North - Eastern of Nigeria, numerous sources of water for consumption and domestic purposes do exist, and research was conducted on the standard quality of the waters for safe drinking water. The results obtained from this study, it revealed that the status of the water sampled from the eight water stations in terms parasites and bacteria contaminations. The water sampled from the eight stations within the study area, subjected microscopical examination for the presence of parasites using parasitological techniques. Water contaminated with parasites can cause illness, especially in people who are very old or very young, and in Immuno - compromised people. According to John [15] in 1993, and an outbreak of Cryptosporidium in the water supply of Milwaukee, Wisconsin, USA, sickened more than 400,000 people and killed more than 100. According WHO [14], stated that safe drinking water or potable water has to be colourless, odourless, and tasteless or agreeable, but any changes from these render it as abnormal.

Some physical examinations of the water sampled were conducted, the results obtained revealed that, all water sampled from the water stations were found to be fit for consumption and health hazard free, i.e., health-risks free. This is because they are colourless, odourless, and tasteless or agreeable, except water sampled from water station $\mathrm{E}$, which was found to be health hazard or health-risks. This is because, it is brownish in colour, when perceived smelled fishy odour and tasted salty. Physico- parameters such as $\mathrm{pH}$, temperature and turbidity of the water sampled from these stations in the said study area were also assessed and found that; the pH mean value was 7.41, which falls within the W.H.O. recommended standard Values (pH 6.5 to 8.3) of potable drinking water. The highest mean value recorded out of the eight stations was found to be in station $\mathrm{F}$ (pH 8.2), and the least mean value was found to be in station A (pH 6.6). These results agree with the works of Gwana et al. [20], and Gwana et al., [2]. All the values obtained from the measurement of $\mathrm{pH}$ of the water sampled from these stations (station $\mathrm{A}$ to $\mathrm{H}$ ) are fit for consumption as table water. It seems, these water stations from the study area are likely to have no impact on health in terms of physical condition $(\mathrm{pH})$ of the water as prescribed by WHO recommended standard parametric values for values table water.

For the temperature; the results obtained from the measurements of the water sampled (sample A to G) in the studied area is inconformity with work of Gwana et al., [2]. It revealed that the parametric mean value was 27.9 OC. This was found to fall within the normal range room temperature within the tropics. The highest recorded mean value was found in station F (32.1 OC), and the least mean value was found to be in station $\mathrm{H}$ with a temperature 
value of 22.1 OC. These water from the water stations are fit for consumption for both human, animals and for domestic uses as prescribed by WHO recommended standard parametric values for values table water.

Among the Physico - parametric values carried out on the water sampled within the studied area; turbidity (TU) was included. The results obtained revealed the mean value of $1.9 \mathrm{TU}$. Water sampled from water station $\mathrm{E}$ had the highest Turbidity Units mean value of 4 TU, and the least mean vale was found in station A, B, and G with 1 TU each respectively. Observation made from these results were obtained from this work, all the water sampled from the eight stations are fit for consumption and meet with the W.H.O. recommended standard parametric values for table water. This work supports the work of Gwana et al., [2] and Gwana et al. [20].

The results of the study also revealed that there were only helminths larvae from water station E, which was larva of a trematode of the genus Schistosoma specie (bifurcated Cercaria) was recovered. Water sampled from the eight water stations within the mentioned study area, were subjected to bacteriological examination for the presence of faecal contaminants such as coliform bacteria, Escherichia coli, and Aerobic mesophilic bacteria. John [15] who reported that, a 1994 study by the Centre for Disease Control and Prevention (CDC - P), estimated that about 900,000 people get sick annually in the United States because of organisms in their drinking water, and around 900 people die annually. Many disease-causing organisms that are present in small numbers in most natural waters are considered pollutants when found in drinking water. Such bacteria and parasites, like Coliform, Giardia lamblia and Cryptosporidium parvum, occasionally turn up in urban and rural water supplies.

W.H.O. [22], stated that diseases - causing organisms that are present in small numbers in most natural waters are considered pollutants when found in drinking water. Safe drinking water and domestic activities; should be free from organisms such as parasites ( 0 count), 1 coliform unit (CFU / ml) of water for Coliform bacteria, $0 \mathrm{CFU} / \mathrm{ml}$ for Escherichia coli and $300 \mathrm{CFU} / \mathrm{ml}$ for Aerobic mesophilic bacteria, and these three bacterial microorganisms are as indicators for drinking water faecal contaminants.

The results obtained from the bacteriological examination revealed that water sampled from station $\mathrm{A}$ and $\mathrm{B}$ contained no coliform, 0 coliform count ( $0 \mathrm{CFU} / \mathrm{ml}$ ), while station $\mathrm{C}, \mathrm{F}, \mathrm{G}$, and $\mathrm{H}$ had $1 \mathrm{CFU} / \mathrm{ml}$ respectively. But, water sampled from the station D had $5 \mathrm{CFU} / \mathrm{ml}$ and station $\mathrm{E}$ had $94 \mathrm{CFU} / \mathrm{ml}$, these were highly contaminated by the pathogens and were an indication of faecal contamination of the water from these water stations. Out of the eight water stations, only two (station D and E) were not safe for consumption and domestic activities. Water stations A, $\mathrm{B}, \mathrm{C}, \mathrm{F}, \mathrm{G}$ and $\mathrm{H}$ were found healthy and safe for consumption and domestic activities as recommended Cheesbrough [1] and WHO, [8], [14], WHO and AOAC [27].

The results of the analysis also revealed that, Escherichia coli (an indicator for faecal contamination) was isolated from the water sampled from the water stations $\mathrm{A}, \mathrm{D}, \mathrm{E}$ and $\mathrm{H}$ with a higher coliform count of the values of $22 \mathrm{CFU} / \mathrm{ml}, 56 \mathrm{CFU} / \mathrm{ml}$ and $18 \mathrm{CFU} / \mathrm{ml}$ for D, E and $\mathrm{H}$ respectively. While water sampled from the water station A had the count value or the bacterial load of $1 \mathrm{CFU} / \mathrm{ml}$. These count values obtained exceeds the standard recommended count values of the parameter values ( $0 \mathrm{CFU} / \mathrm{ml}$ ) for safe drinking water and domestic activities and it was not free of health hazards in terms of the bacterial organisms isolated. But, water sampled from the water stations $\mathrm{B}, \mathrm{C}, \mathrm{F}$ and $\mathrm{G}$ had the count value of $0 \mathrm{CFU} / \mathrm{ml}$ each, and water sampled from these stations were free of health hazards, therefore, fit for consumption and domestic activities.

Also from this research study, Aerobic mesophilic bacterial organism was isolated and counted in all the water sampled from the eight water stations mentioned earlier, but only water sampled from the water station $\mathrm{E}$ had the highest count value of $313 \mathrm{CFU} / \mathrm{ml}$, and this exceeded the standard count value (300 CFU / ml of water) of the standard recommended parameter values for safe drinking water and domestic activities, thus not free from health hazards. To this reason, it is therefore, not fit for consumption and domestic activities. Samples from the water stations H, A, D, C, F, B and G had the count values of $286 \mathrm{CFU} / \mathrm{ml}, 283 \mathrm{CFU} / \mathrm{ml}, 261 \mathrm{CFU} / \mathrm{ml}, 104 \mathrm{CFU} / \mathrm{ml}, 51$ $\mathrm{CFU} / \mathrm{ml}, 23 \mathrm{CFU} / \mathrm{ml}$ and $11 \mathrm{CFU} / \mathrm{ml}$, sequentially arranged in descending order of their magnitude of the count values obtained, and all were below the standard count value $(300 \mathrm{CFU} / \mathrm{ml})$ of the standard recommended parameter value for safe drinking water and domestic activities by Cheesbrough [1], WHO [8], [22]; W.H.O. and A.O.A.C. [27]. Thus, stations A, B, C, D, F, G and H were free from health hazards, and therefore, fit for consumption and domestic activities, and only water from station $\mathrm{E}$ was found unfit for wholesome and domestic purposes (activities). 


\section{CONCLUSION}

This research study in the said study area revealed some findings on some physical parametric values (colour, odour, taste, $\mathrm{pH}$, temperature and turbidity), helminths ova, protozoan cysts, and bacterial indicators of the Faecal contaminants (coliform, Escherichia coli and Aerobic mesophilic bacterial organism) from the eight water stations within the community of College of Agriculture and its environs, Maiduguri. The physical parameters of the water sampled met the W.H.O. recommended standard parametric values for table water in terms of $\mathrm{pH}$, temperature and turbidity. Furthermore, in this study the results obtained revealed that the water sampled contained only helminths larva and some bacterial of Faecal contaminants. Therefore, apart from the water sampled from the water station E, (which was water sourced from the river Kumodu Gana), all the water sampled from these stations were fit for consumption and domestic activities, i.e. were found wholesome and domestic purposes, as recommended by Cheesbrough (2010); WHO [8], [14]., WHO and AOAC [27].

\section{RECOMMENDATIONS}

Based on the findings of this studied, the following recommendations were made; The community of the studied area should be enlightened on the World Health Organizations' recommended standard parametric values for drinking water and its purification. The community of the studied area should be enlightened on the sanitation measures in order to keep their household, environment and surrounding free from waste materials which should be burnt and buried in a pit. The Government, Non-Governmental Organization (NGO) or any authority concerned should assist and build more Bore Holes with polythene (PVC) pipes networks for safe water (drinking and domestic purposes) distributions within the community studied. Furthermore, intensive research studies in the community and its environs are highly recommended.

\section{SOURCES OF FUNDING}

This research received no specific grant from any funding agency in the public, commercial, or not-for-profit sectors.

\section{CONFLICT OF INTEREST}

The author have declared that no competing interests exist.

\section{ACKNOWLEDGMENT}

It is a great pleasure to acknowledge the great role played by, especially, Laboratory Unit, Animal Health Production and Technology Department, Mohamet Lawan College of Agriculture, Maiduguri, NISLT, Ibadan and NAFDAC, Maiduguri, Nigeria for their support and an assistance given to us. We owe particular thanks to all those authors and researchers cited in this piece of work and most grateful to all persons who have helped or assisted in one way or the other in the course of carrying out this research study. Thanking you and very grateful to you all.

\section{REFERENCES}

[1] Cheesbrough, M. Water Related Disease and Testing of Water Supply, In: District Laboratory Practice in Tropic Countries, Part Two, Cambridge University Press, 2nd Edition; 2010, pp. 143 - 157.

[2] Gwana, A. M., Biu, A. A., Mu'azu, A. K., Abubakar, A., Hamra, A. A., Mustapha, B. M. Physico - Chemical Analysis of Domestic Water Used by the Community of College of Agriculture and Its Environs, Maiduguri, Nigeria. Sumerianz Journal of Biotechnology, vol. 2, No. 10, 2019, pp: 82 - 90.

[3] Association of Analytical Chemists (AOAC). Official Methods of Analysis. Association of Official Analytical Chemists, AOAC Press, Gaithersburg, USA, 15th Edition; 1990, pp.

[4] Cainncross, G. and Feachen, R. G. Environmental Health Engineering in the Tropic, In: Wiley, an Introductory Text Book, 4th Edition; 1983, pp. 144 - 149. 
Abdullahi Abubakar Biu, Gwana Adamu Mohammed, Mu'azu Abdullahi Kofar Na'isa, Abubakar Musa, Abubakar Aliyu, and Mohammed Lawan Marte

[5] Gardon, M. F. Silversion Water and Waste Water Technology, (Silversion), Ohn - Wiley and Sons Ltd, 1st Edition; 1978, pp. 1 - 68.

[6] Gwana, A. M., Mshelia, N. H., Abdullahi, M. M., Auwal, M. S., Bagudu, B. Y., Mala, B. M., Abdullahi, H. M. and Sadiq, A. B. Effects of Domestic Water Wastes on Water from Shallow - Wells in Moduganari, Nigeria, International Journal of Environmental Monitoring and Analysis, 2 (4); 2014b, pp. 185 - 190.

[7] World Health Organization (WHO). Guidelines for Drinking Water Quality, 1th Edition, Volume 1; 1995, pp. $3-23$.

[8] World Health Organization (WHO) (2011). Guidelines for Drinking Water Quality, 4th Edition, Volume 1; pp. $23-30$.

[9] Abdullahi, H. Important and existence of water; In: Effect of Domestic Liquid Waste on Ground Water Quality of Shallow Well, (Cases Study of Moduganari, Maisandari Ward, Maiduguri). A Final Year Project (Unpublished), Department of Agriculture and Bio - Environmental Engineering, Ramat Polytechnic, Maiduguri; 2013, pp. $4-8$.

[10] Frazier, W. C. and Westhoff, D. C. Food Microbiology, McGray Hill Books Co. 4th Edition; 1988, pp. 63 - 487.

[11] Shmueli, D. F. Water Quality in International River Basin, In: Political Geography 18; 1999, pp. 437 - 476.

[12] Bonnie, W. R. Microsoft® Encarta ® 2008 [DVD] Remond, W. A: Microsoft Corporation, (C), 2008,1997 2007.

[13] Umaru, B. W., Gwana, A. M., Wanas, L. N. and Halima, M. B. Assessments of Biological Water Quality and Condition Factors of Clarias gariepinus in Lake Alau, North - Eastern Nigeria, International Journal of Natural Resources Ecology and Management, 2 (3); 2016, pp. 14 - 25.

[14] World Health Organization (WHO). Guidelines for Drinking Water Quality, 3th Edition, Volume 1; 2004, pp. $34-78$.

[15] John, H. Microsoft@ Encarta ® 2008 [DVD]. Remond, W. A: Microsoft Corporation, C, 2008, 1997 - 2007.

[16] Philip, M. What is a Special about Water? In: Advance Chemistry, Cambridge University Press, U.K, Low Price Edition; 2004, pp. $558-568$.

[17] Ekubo, A. A. and Abowei, J. F. N. Review of Some Water Quality Management Principle in Culture Fisheries, Research Journal of Applied Sciences, Engineering and Technology, 3 (2); 2011, pp. 1342 - 1357.

[18] Babale, M. L. Limnology and Zooplankton Distribution of Makwaye Lake, Zaria. M.Sc. Thesis, Ahmadu Bello University, Zaria; 1989, pp. 51.

[19] Ali, A. N. Ecological study on some water characteristics used in fish farms and their relation to fish productivity. Ph.D. Thesis: Chemistry Department, Faculty of Science, Al-Azhar University, Egypt; 2007, pp. 306.

[20] Gwana, A. M., Bako, M. M., Auwal, M. S., Bagudu, B. Y., Kadai, K. I., Sadiq A. B., and Halima, M. B. Physico Microbiological and Chemical Examination of Domestic Water Used by the College of Agriculture Community, Maiduguri, North - Eastern Nigeria, International Journal of Science, Technology and Society, 2 (4); 2014a, pp. $63-68$.

[21] Umaru, B, W., Harana, A. B., Gwana, A. M., Wanas, L. N., Bukar - Kolo, M. Y. and Mohammed, U. K. Examination of the Stomach Contents of Two Fish Species (Clarias gariepinus and Oreochromis niloticus) in Lake Alau, North - Eastern Nigeria, Agriculture, Forestry and Fisheries, 3 (5); 2014), pp. 405 - 409.

[22] World Health Organization (WHO). Conference on World Water Quality, Guidelines for Drinking Water Quality, Conference Reports, Geneva, 1993, pp:

[23] Wikipedia. Drinking Water Quality Standard, In: Wikipedia Encyclopedia; 2013, pp. 1 - 4.

[24] Gwana, A. M., Auwal, M. S., Bagudu, B. Y., and Gazali, Y. A. Study Area and Location, in: Comparative of Parasitological Diagnostic Techniques in the Survey of Haemoparasites of Camel Slaughtered in Maiduguri Central Abattoir, North - Eastern Nigeria, Journal of Science, 1 (2); 2013, pp. 57 - 65.

[25] National Population Commission. Vital Statistic Unit, Census De Facto, Census Report, Gidan Madara, Maiduguri, Borno State, Nigeria, 2006.

[26] Stroud, K. A. and Booth, D. J. Statistical Package, In: Engineering Mathematics, www.Palgrave.com / Stroud, Palgrave, GB, London, 5th Edition; 2001, pp. 1130 - 1139.

[27] World Health Organization (WHO) / Association of Analytical Chemists (AOAC). Standard Values of Safe Drinking Water as Reports, Revision 2, Section 973, 42B (b), 2007. 